\title{
PENGARUH MODEL PEMBELAJARAN KUIS INTERAKTIF WHO WANTS TO BE A MILLIONAIRE TERHADAP HASIL BELAJAR SISWA
}

\author{
Ebid Rocky Alfatikh \\ SMAN 3 Sampang
}

\begin{abstract}
Abstrak : Pandemi covid-19 di Indonesia sejak 2020 membuat pemerintah menutup sekolah sampai saat ini. Saat ini sebagian sekolah sudah melaksanakan tatap muka $25 \%$ dan $50 \%$. Setelah sekian lama tidak pembelajaran tatap muka siswa tentu harus dirangsang untuk semangat dalam belajar. Salah satu caranya adalah dengan model pembelajaran kuis interaktif. Hal ini bertujuan agar siswa aktif berpartisipasi saat pembelajaran. Jenis penelitian yang digunakan dalam penelitian ini adalah penelitian eksperimen semu (quasi experimental research). Penelitian ini menggunakan desain pretest dan posttest control group design untuk mengetahui pengaruh model pembelajaran kuis interaktif who wants to be a millionaire tehadap hasil belajar siswa. hasil dari penelitian bahwa kelas yang melakukan model pembelajaran kuis interaktif who wants to be a millionaire lebih meningkat hasil belajarnya dari yang awalnya rata rata 82,25 dari sebelumnya saat pretest sebesar 70,25. Kenaikan cukup signifikan sebesar 12 angka. Dilihat dari siswa yang tuntas juga meningkat drastis dari yang awalnya hanya 6 siswa saat pretest menjadi 12 siswa saat posttest.
\end{abstract}

Kata kunci : model pembelajaran kuis interaktif, hasil belajar, penelitian eksperimen

Abstract: The Covid-19 pandemic in Indonesia since 2020 has forced the government to close schools until now. Currently, some schools have implemented face-to-face learning of $25 \%$ and $50 \%$. After a long time, face-to-face learning, students certainly have to be stimulated for enthusiasm in learning. One way is with an interactive quiz learning model. This aims to make students actively participate in learning. This type of research used in this research is quasi experimental research (quasi experimental research). This study uses a pretest and posttest control group design to determine the effect of the interactive quiz learning model who wants to be a millionaire on student learning outcomes. The result of the research shows that the class that does the interactive quiz learning model who wants to be a millionaire has more increased learning outcomes from the initial average of 82.25 from the previous time of 70.25 pretest. The increase is quite significant by 12 points. Judging from the students who completed it also increased dramatically from only 6 students at the pretest to 12 students at the posttest.

Keywords: interactive quiz learning model, learning outcomes, experimental research

\section{A. PENDAhULUAN}

Pada tahun 2020 tepatnya bulan maret Indonesia mengalami awal masa pandemi covid-19. Pemerintah lantas mengumumkan status darurat nasional bencana non alam. Hal ini memberikan dampak kepada setiap sendi kehidupan di indonesia termasuk pendidikan di dalamnya. Bahkan menurut data UNESCO (2020) terdapat 1,37 miliar siswa yang dirumahkan dan terpaksa belajar dari rumah. 
Hal tersebut juga terjadi di Indonesia. Dikala pandemi saat ini masih didominasi dengan kegiatan pembelajaran daring. Kegiatan daring ini bukan tanpa masalah, keterbatasan sarana dan akses digital sangat dirasakan oleh anak anak sekolah.

Hal tersebut menjadi salah satu bahan kajian yang dilakukan oleh para pakar Pendidikan di seluruh dunia, mengenai bagaimana agar pembelajaran tetap berjalan dan kualitas pembelajaran tidak menurun, walaupun terdapat tantangan yang begitu besar, termasuk menjawab apa dan bagaimana strategi yang dapat dilakukan Luthra (2020).

Guru, dosen dan Pengembang Teknologi Pembelajaran memiliki peran penting dalam hal mengembangkan inovasi, ide atau gagasan untuk pemanfaatan teknologi dalam pembelajaran. Made Wena (2011) menyatakan keuntungan pembelajaran dengan teknologi dapat menciptakan iklim belajar yang efektif bagi siswa yang lamban dalam pembelajaran, merangsang siswa dalam mengerjakan latihan dan dapat menyesuaikan kecepatan kecepatan belajar dapat sesuai dengan kemampuan siswa. Salah satu pengembangan teknologi Pendidikan adalah dengan melakukan pembelajaran berbasis permainan atau gamed based learning.

Konsep dalam penelitian ini mengacu pada game based learning yang merupakan teknik pembelajaran berlandasan permainan yang dapat membantu meningkatkan potensi dan kualitas pelajar dalam menyerap pengetahuan. Ryan Dellos (2015) menyatakan bahwa pembelajaran berlandasan permainan merupakan alat yang dapat membantu peserta didik dalam menyelesaikan masalah, meningkatkan pemikiran kritis dan membuat sebuah penilaian dalam proses pembelajaran .

Huang (2011) menyatakan penelitian pada bidang desain pendidikan telah menunjukkan bahwa game based learning atau pembelajaran berbasis permainan adalah salah satu alat yang efektif dalam pengajaran terutama untuk menjaga motivasi keberlanjutan belajar.

Peneliti mencoba menerapkan model pembelajaran berbasios permainan yang diadaptasi dari aturan kuis interaktif who wants to be a millionaire untuk merangsang siswa berpartisipasi dalam kegiatan pembejaran yang berbasis kuis tersebut. Penerapan model ini bertujuan untuk menggali efektivitas model tersebut untuk memulai pembelajaran yang telah memasuki fase luring $50 \%$ saat ini di beberapa wilayah di Indonesia. Secara umum diketahui permainan bersifat menyenangkan dan motivasi.

Pembelajaran yang bersifat pendekatan permainan yang melibatkan partisipasi peserta didik dalam teknologi 
digital, menunjukkan keingingan yang lebih besar dalam melanjutkan proses pembelajaran berikutnya dibandingan pembelajaran bersifat konvensional. Rumusan permasalahan penelitian ini terletak pada apakah hasil eksperimen model pembelajaran kuis interaktif who wants to be a millionaire berpengaruh secara signifikan terhadap hasil belajar siswa. Diharapkan dengan penerapan model pembelaaran yang berbasis kuis isteraktif dalam hal ini model pembelajaran kuis interaktif who wants to be a millionaire bisa meningkatkan hasil belajar siswa.

\section{B. METODE}

Dalam penelitian ini, penulis menggunakan pendekatan kuantitatif dengan penelitian eksperimen, dimana suatu hal dapat diteliti adanya pengaruh atau tidak dalam penelitian tersebut. Penelitian kuantitatif itu menelaah obyek dengan cara menghitung dengan menggunakan satuan angka untuk menetapkan ukuran obyek yang dipelajari baik yang riil maupun obyek abstrak. Pemahaman konsep dasar penelitian kuantitatif tidak bisa dipahami dari satu aspek tertentu, melainkan harus ditinjau dari beberapa aspek. Konsep dasar penelitian kuantitatif digunakan beberapa konsep, yaitu pendekatan, metode, data, dan analisis (Widodo, 2009:19).

Jenis penelitian yang digunakan dalam penelitian ini adalah penelitian eksperimen semu (quasi experimental research). Eksperimen ini bukan merupakan eksperimen murni tetapi seperti murni atau seolah-olah murni karena berbagai hal terutama berkenaan dengan pengontrolan variabel kemungkinan sukar sekali dapat digunakan eksperimen murni (Nana Syaodih Sukmadinata, 2010: 207).

Penelitian ini menggunakan desain pretest dan posttest control group design untuk mengetahui pengaruh model pembelajaran kuis interaktif who wants to be a millionaire tehadap hasil belajar siswa. Dalam design ini terdapat dua kelompok yaitu kelompok eksperimen dan kelompok kontrol yang dipilh secara acak, kemudian diberi pretest untuk mengetahui keadaan awal, adakah perbedaan antara kelas eksperimen dan kelas kontrol (Sugiyono, 2009: 113). Kelas kontrol diberi perlakuan dengan menggunakan metode ceramah, sedangkan kelas eksperimen diberi perlakuan dengan menggunakan model pembelajaran kuis interaktif who wants to be a millionaire.

Setelah selesai perlakuan kedua kelas tersebut diberi posttest yang bertujuan untuk mengukur prestasi belajar peserta didik atas perlakuan yang telah diberikan. Adapun rancangan eksperimen dalam penelitian ini ditunjukkan dalam Tabel 1. 
Tabel 1 Desain Pretest-Posttest Control Group Design

\begin{tabular}{llll}
\hline Kelompok & $\begin{array}{l}\text { Pre } \\
\text { test }\end{array}$ & Perlakuan (X) & $\begin{array}{l}\text { Post } \\
\text { test }\end{array}$ \\
\hline KE & O1 & $\begin{array}{l}\text { Model pembelajaran kuis interaktif who want to be a } \\
\text { millionaire }\end{array}$ & O2 \\
\hline KK & O3 & Ceramah & O4 \\
\hline
\end{tabular}

Keterangan :

KE: Kelompok Eksperimen (kelompok yang diberi perlakuan pekerjaan rumah)

KK: Kelompok Kontrol (kelompok yang tidak diberi perlakuan pekerjaan rumah)

O1: Pre-test (kelompok eksperimen)

O2: Post-test (kelompok eksperimen)

O3: Pre-test (kelompok kontrol)

O4: Post-test (kelompok kontrol)

$\mathrm{X}$ : Perlakuan

Dari adanya penelitian eksperimen dengan pendekatan kuantitatif ini peneliti bermaksud untuk memperoleh serta mengetahui perbedaan hasil belajar siswa yang menerapkan model pembelajaran kuis interaktif who wants to be a millionaire dan tidak menerapkannya. Kelompok eksperimen pada penelitian ini yakni kelas X-MIPA 1, Sedangkan Kelompok Kontrol yakni kelas X-MIPA 2. Sebelum melaksanakan penelitian peneliti melaksanakan uji coba instrumen. Tujuan diadakannya uji coba adalah diperolehnya informasi mengenai kualitas instrumen yang digunakan, yaitu informasi mengenai sudah atau belum memenuhi persyaratan. Menurut Suharsimi Arikunto (2002: 145) "Baik buruknya instrumen akan berpengaruh terhadap benar tidaknya data yang diperoleh, sedangkan benar tidaknya sangat menentukan bermutu tidaknya hasil penelitian".

Subjek uji coba instrumen diambil dari anggota populasi yang tidak terpilih sebagai sampel. Adapun uji coba instrumen penelitian dikenakan pada kelas X-MIPA 4. Menurut Suharsimi Arikunto (2002: 145) "validitas adalah suatu ukuran yang menunjukkan tingkattingkat kevalidan atau kesahihan suatu instrumen. Pengujian validitas instrumen dimaksudkan untuk mendapatkan alat ukur yang sahih dan terpercaya. Menurut Suharsimi Arikunto (2003: 72) "Sebuah instrumen dikatakan valid apabila mampu mengukur apa yang diinginkan”. Tinggi rendahnya validitas instrumen menunjukkan sejauh mana data yang terkumpul tidak menyimpang dari gambaran tentang validitas yang dimaksud. Hasil uji coba tersebut dianalisis dengan menggunakan rumus korelasi Product Moment dari Karl Pearson. Adapun rumus Product 
Moment. Selanjutnya butir-butir yang tidak valid atau gugur tidak diikutsertakan dalam pengambilan penelitian. Hasil uji validitas dapat dilihat pada tabel 2 .

Tabel 2 Hasil Uji Validitas Butir Soal

\begin{tabular}{|c|c|c|c|}
\hline Item & Rxy & Rtabel & Ket. \\
\hline 1 & 0.591 & 0.514 & VALID \\
\hline 2 & 0.488 & 0.514 & TIDAK VALID \\
\hline 3 & 0.699 & 0.514 & VALID \\
\hline 4 & 0.997 & 0.514 & VALID \\
\hline 5 & 0.728 & 0.514 & VALID \\
\hline 6 & 0.699 & 0.514 & VALID \\
\hline 7 & 0.415 & 0.514 & TIDAK VALID \\
\hline 8 & 0.591 & 0.514 & VALID \\
\hline 9 & 0.699 & 0.514 & VALID \\
\hline 10 & 0.728 & 0.514 & VALID \\
\hline 11 & 0.415 & 0.514 & TIDAK VALID \\
\hline 12 & 0.591 & 0.514 & VALID \\
\hline 13 & 0.997 & 0.514 & VALID \\
\hline 14 & 0.591 & 0.514 & VALID \\
\hline 15 & 0.591 & 0.514 & VALID \\
\hline 16 & 0.997 & 0.514 & VALID \\
\hline 17 & 0.997 & 0.514 & VALID \\
\hline 18 & 0.445 & 0.514 & TIDAK VALID \\
\hline 19 & 0.728 & 0.514 & VALID \\
\hline 20 & 0.997 & 0.514 & VALID \\
\hline 21 & 0.699 & 0.514 & VALID \\
\hline 22 & 0.415 & 0.514 & TIDAK VALID \\
\hline 23 & 0.997 & 0.514 & VALID \\
\hline 24 & 0.997 & 0.514 & VALID \\
\hline 25 & 0.591 & 0.514 & VALID \\
\hline 26 & 0.997 & 0.514 & VALID \\
\hline 27 & 0.591 & 0.514 & VALID \\
\hline 28 & 0.997 & 0.514 & VALID \\
\hline 29 & 0.997 & 0.514 & VALID \\
\hline 30 & 0.728 & 0.514 & VALID \\
\hline
\end{tabular}

(Sumber: Hasil pengolahan data, 2021)

Berdasarkan tabel di atas menunjukkan hasil uji validitas instrumen terdapat 25 butir soal yang valid dan terdapat 5 butir soal yang gugur. Sehingga butir soal 
yang valid tersebut dapat digunakan untuk penelitian.

Selain uji validitas, peneliti uga melakukan uji reliabilitas. Menurut Suharsimi Arikunto (2002: 154), "Reliabilitas menunjuk pada satu pengertian bahwa suatu instrumen cukup dapat dipercaya untuk digunakan sebagai alat pengumpul data karena instrumen tersebut sudah baik".

Menurut Suharsimi Arikunto (2006: 276), cara menggunakan interpretasi terhadap koefisien korelasi yang diperoleh, atau nilai r. Interpretasi tersebut adalah seperti Tabel 3.

Tabel 3 Interpretasi nilai $r$

\begin{tabular}{cc}
\hline Besarnya nilai $\mathbf{r}$ & Interpretasi \\
\hline Antara 0,800 sampai dengan 1,00 & Tinggi \\
\hline Antara 0,600 sampai dengan 0,800 & Cukup \\
\hline Antara 0,400 sampai dengan 0,600 & Agak rendah \\
\hline Antara 0,200 sampai dengan 0,400 & Rendah \\
\hline Antara 0,200 sampai dengan 0,000 & Sangat Rendah \\
\hline
\end{tabular}

Reliabilitas instrumen prestasi belajar digunakan rumus K-R 20, sebagai berikut:

$r 11=\left(\frac{K}{K-1}\right)\left(\frac{V t-\sum p q}{V t}\right)$

Keterangan:

r11 : Reliabilitas instrumen

$\mathrm{k}$ : Banyaknya butir pertanyaan

$\mathrm{Vt} \quad$ : Varians total

$\mathrm{p} \quad: \frac{\text { Banyaknya subjek yang skornya } 1}{N}$

q $\quad: \frac{\text { Banyaknya subjek yang skornya } 0}{N}$

(Suharsimi Arikunto, 2002: 155)

Berdasarkan hasil uji coba instrumen menunjukkan nilai reliabilitas sebesar 0,981. Karena nilai interpretasi lebih dari 0,600, maka dinyatakan reliabel dalam kategori tinggi.

\section{HASIL DAN PEMBAHASAN \\ C.1. HASIL PENELITIAN}

Sebelum menganalisis hasil penelitian uji persyaratan analisis harus dilakukan, peneliti menggunakan uji normalitas, uji homogenitas dan uji hipotesis (independent uji test). Uji Normalitas digunakan untuk mengetahui apakah skor untuk variabel berdistribusi normal atau tidak.

Uji normalitas merupakan analisis statistik yang pertama dilakukan dalam rangka analisis data. Kepastian terpenuhinya syarat normalitas akan menjamin dapat dipertanggungjawabkan. Analisis data dapat dilanjutkan apabila data berdistribusi normal. Pengujian normalitas dengan KolmogorovSmirnov. 


$$
\mathrm{KS}=1,36 \sqrt{\frac{n 1+n 2}{n 1 \times n 2}}
$$

Keterangan:

KS : harga Kolmogorov-smirnov yang dicari

n1 : Jumlah sampel yang diobservasi atau diperoleh

n2 : Jumlah sampel yang diharapkan

(Sugiyono, 2006: 152)

Data dikatakan normal, apabila nilai signifikan lebih besar 0,05 pada $(\mathrm{P}>0,05)$. Sebaliknya, apabila nilai signifikan lebih kecil dari 0,05 pada $(\mathrm{P}<0,05)$ maka data dikatakan tidak normal.

Hasil uji normalitas hasil belajar baik di kelas control maupun kelas eksperimen adalah 0,2. Nilai signifikansi (p) pada uji Kolmogorov-Smirnov adalah 0.2 ( $\mathrm{p}>0.05$ ), sehingga berdasarkan uji normalitas Kolomogorov-Smirnov data berdistribusi normal.

Selanjuitnya uji homogenitas, dalam uji homogenitas, dengan harga $\mathrm{F}$ yang diharapkan adalah harga $\mathrm{F}$ yang tidak signifikan yaitu harga $\mathrm{F}$ empirik yang lebih kecil daripada harga $F$ teoritik. Pengujian homogenitas dengan rumus:

$$
\mathrm{F} \text { hitung }=\frac{\text { Var terbesar }}{\text { Var terkecil }}
$$

Keterangan:

Var terbesar : nilai variansi yang lebih besar dari dua sampel yang dibandingkan

Var terkecil : nilai variansi yang lebih kecil dari dua sampel yang dibandingkan
Taraf signifikasi yang digunakan adalah $\alpha=0,05$. Uji homogenitas menggunakan SPSS dengan kriteria yang digunakan untuk mengambil kesimpulan apabila $\mathrm{F}$ hitung lebih besar dari $\mathrm{F}$ tabel maka memiliki varian yang homogeny. Akan tetapi apabila F hitung lebih besar dari $\mathrm{F}$ tabel, maka varian tidak homogen.

Hasil dari homogenitas menunjukkan bahwa nilai $\mathrm{F}$ hitung adalah 0,86. Dengan demikian dapat dibuktikan bahwa varian data hasil belajar di kelas eksperimen dan kelas control adalah sama.

Uji hipotesis menggunakan uji-t (independent uji test) yaitu menguji perbedaan rata-rata dua kelompok yang saling beban dengan rumus:

$$
t=\frac{\overline{X_{1}}-\overline{X_{2}}}{\sqrt{\left(\frac{s_{1}^{2}}{N_{1} 1}\right)\left(\frac{s_{2}^{2}}{N_{2} 1}\right)}} .
$$

Keterangan:

$X_{1}$ : Mean pada distribusi sampel 1

$X_{2}$ : Mean pada distribusi sampel 2

$N_{1}$ : Jumlah individu pada sampel 1

$N_{2}$ : Jumlah individu pada sampel 2

$S_{1}^{2}$ : Nilai varian pada distribusi sampel 1

$S_{2}^{2}$ : Nilai varian pada distribusi sampel 2

Taraf signifikansi yang digunakan $\alpha=0,05$. Kriteria keputusan $\mathrm{H} 0$ diterima jika $\mathrm{t}$ hitung $\geq \mathrm{t}$ tabel.

Taraf signifikansi 2 arah (t-tailed) $0.000<0.05$. Sehingga terdapat perbedaan skor point yang berarti antara kelompok kontrol dan perlakuan. Berdasarkan nilai deskriptifnya terbukti 
kelompok eksperimen dengan model kuis interaktif who wants to be a millionaire mendapat skor lebih tinggi.

Penelitian diawali dengan melakukan pembelajaran terhadap kedua kelas yaitu kelas eksperimen dan kelas kontrol diberikan pretest berbentuk soal pilihan ganda untuk mengetahui seberapa besar tingkatan hasil belajar siswa pada Materi pelajaran Geografi. Pada akhir pembelajaran, kedua kelas tersebut diberikan posttest berupa soal yang sama dengan soal pretest. Berikut hasil data yang diperoleh pada penelitian di kelas eksperimen dan kelas kontrol dapat dilihat pada tabel 4 .

Tabel 4 nilai pretest dan posttest pada kelas eksperimen dan kelas control

\begin{tabular}{llll}
\hline \multicolumn{1}{c}{ Kelas } & \multicolumn{3}{c}{ Nilai Pretest } \\
\cline { 2 - 4 } Eksperimen & Tertinggi & Terendah & Rata-rata \\
\hline Kontrol & 80 & 60 & 70,25 \\
\hline \multirow{2}{*}{ Eksperimen } & 80 & 60 & 70,5 \\
\hline Kontrol & 92 & Nilai Postest \\
\hline
\end{tabular}

Pada Tabel 4 diatas terlihat bahwa saat pelaksanaan pretest rata-rata pada kelas kontrol lebih unggul dibandingkan dengan kelas eksperimen terdapat selisih rata-rata 0,25 . Nilai pretest yang tertinggi pada kelas eksperimen dan kontrol sama yakni 80 , untuk nilai terendah pada kelas eksperimen dan control juga sama yaitu 60.

Pada pelaksanaan postest mengalami peningkatan antara kelas eksperimen dan kelas kontrol. Kelas eksperimen mengalami peningkatan lebih tinggi dibandingkan dengan kelas kontrol setelah pelaksaanaan postest, rata-rata pada kelas eksperimen mencapai 82,25 dan kelas kontrol 74 .
Kemudian untuk ketuntasan siswa pada kelas eksperimen yang semula 6 menjadi 12 siswa, dan pada kelas kontrol yang semula 6 menjadi 8 siswa. Untuk nilai tertinggi terjadi kenaikan pada kelas eksperimen dan kelas kontrol, dan nilai terendah pada kelas eksperimen dan kelas kontrol terjadi kenaikan. Nilai tertinggi pada kelas eksperimen yaitu 92 dan kelas kontrol 84, sedangkan nilai terendah pada kelas eksperimen 72 dan kelas kontrol 60.

Dapat disimpulkan bahwa kelas eksperimen dan kelas kontrol mempunyai kemampuan awal yang sama dan setelah diberikan perlakuan terhadap perbedaan hasil belajar pada kelas 
eksperimen yang menggunakan model kuis interaktif who wants to be a millionaire dengan kelas kontrol yang menggunakan model ceramah.

Uji tes awal (Pretest) yang dilakukan peneliti diperoleh dari rata-rata pada kelas eksperimen untuk pretest adalah 70,25 dan terdapat 6 siswa yang sudah tuntas dan mencapai KKM sebesar 75 dari 15 siswa. Rata-rata pada kelas kontrol 70,5 dan terdapat 6 siswa yang sudah mencapai KKM dari 15 siswa. Pada tahap selanjutnya adanya pemberian perlakuan pada kelas eksperimen yaitu dengan menggunkan model kuis interaktif who wants to be a millionaire. Hasil belajar adalah kemampuan-kemampuan yang dimiliki siswa setelah menerima sebuah pengalaman belajar, maka hasil belajar yang diperoleh siswa setelah memperoleh pengalaman dari adanya pemberian perlakuan menggunakan model kuis interaktif who wants to be a millionaire menunjukkan kelas eksperimen pada nilai posttest memperoleh rata-rata 82,25 dengan siswa tuntas 12 dari 15 siswa yang mencapai KKM. Pada nilai posttes kelas kontrol diperoleh rata-rata 74 untuk siswa tuntas sebanyak 8 dari 15 siswa yang mencapai KKM.

Adanya perlakuan yang berbeda maka terdapat perbedaan hasil belajar antara kelas eksperimen dan kelas kontrol. Perbedaan terjadi karena pada proses pembelajaran di kelas eksperimen menggunakan model kuis interaktif who wants to be a millionair sehingga siswa memperoleh peningkatan pemahaman terhadap materi yang dipelajari dan mengeksplorasi ide serta pendapat yang disampaikan siswa sehingga suasana di dalam kelas menjadi hidup dan membuat siswa menjadi bersemangat sehingga menyebabkan hasil belajar siswa menjadi baik dari sebelumnya, dengan demikian dapat disimpulkan bahwa hasil belajar pada kelas eksperimen lebih baik dari pada kelas kontrol.

\section{C.2. PEMBAHASAN}

Hasil yang didapat dari penelitian ini sejelan dengan beberapa penelitian diantaranya penelitian yang dilakukan Suci (2016) yang menemukan bahwa media Kuis Interaktif pada mata pelajaran Jaringan Dasar mendapat respon yang sangat baik bagi siswa sebagai media pembelajaran di SMK Negeri 7 Surabaya.

Selain penelitian eksperimen, terdapat penelitian PTK atau action research yang sejenis dengan penelitian ini yakni penelitian yang dilakukan oleh Sulistyowati (2018). Penelitian tersebut menemukan bahwa Melalui penerapan model pembelajaran Quiz Team dapat meningkatkan motivasi belajar PKn materi Pemerintah Kabupaten dan Kota pada siswa kelas IV SD 4 Klaiwungu Kudus Tahun Pelajaran 2018/2019. Hal 
ini terbukti bahwa motivasi belajar siswa pada akhir siklus 2 reratanya mencapai $90 \%$.

Penelitian yang dilakukan Brian Robert Cook \& Andrea Babon (2016) menemukan bahwa Pembelajaran aktif semakin dipromosikan dalam institusi pendidikan tinggi untuk membantu siswa mengembangkan pemikiran tingkat tinggi dan menghubungkan pengetahuan dengan makna. Hal ini mendukung hasil penelitian ini karena dengan penerapan model pembelajaran kuis interaktif dapat meningkatkan hasil belajar siswa.

Penelitian yang dilakukan oleh juga mendukung hasil penelitian ini dikarenakan Ketika model pembelajaran kuis interaktif diterapkan kemampuan pemecahan masalah matematis metode kuis interaktif lebih baik dari model pembelajaran konvensional. Berdasarkan hasil analisis dan pembahasan terhadap data penelitian diperoleh bahwa terdapat pengaruh yang berbeda pada kemampuan pemecahan masalah matematis antara mahasiswa yang kelasnya menerapkan metode kuis interaktif, mahasiswa yang dikelasnya menerapkan model pembelajaran konvensional pada pokok pembahasan trigonometri.

Penelitian yang dihasilkan oleh Cahyaningtyas (2015) tentang pengaruh model pembelajaran team quiz dan team games tournament (TGT) dalam scientific approach terhadap sikap ilmiah geografi siswa memiliki kemiripan dengan model yang diambil dalam penelitian ini, namun penelitian ini memiliki ciri khas yang lebih spesifik dikarenakan penggunaan aturan yang diadaptasi dari kuis popular who wants to be a millionaire. Kemiripan hasil juga didapatkan dimana hasil penelitian tersebut dapat disimpulkan:

1) Terdapat pengaruh penggunaan model pembelajaran Team Quiz terhadap sikap ilmiah geografi siswa kelas XI IPS MAN Yogyakarta 1. Hal ini ditunjukkan dari hasil uji-t angket awal dan angket akhir sikap ilmiah geografi siswa kelas eksperimen 1 yang memiliki nilai thitung > ttabel $(3,227>2,039)$ dan dilihat dari signifikansi yaitu sig. (2-tailed) 0,003 $<0,05$.

2) terdapat pengaruh penggunaan model pembelajaran Team Games Tournament (TGT) terhadap sikap ilmiah geografi siswa kelas XI IPS MAN Yogyakarta 1. Hal ini ditunjukkan dari hasil uji-t angket awal dan angket akhir sikap ilmiah geografi siswa kelas eksperimen 2 yang memiliki nilai thitung $>$ ttabel $(2,534>2,039)$ dan dilihat dari signifikansi yaitu sig. (2-tailed) 0,017 $<0,05$.

3) terdapat perbedaan pengaruh antara model pembelajaran Team Quiz dan Team Games Tournament (TGT) 
terhadap sikap ilmiah geografi siswa kelas XI IPS MAN Yogyakarta 1 Tahun Ajaran 2014/2015. Hal ini ditunjukkan dari hasil uji-t angket akhir sikap ilmiah geografi siswa kelas eksperimen 1 dan kelas eksperimen 2 yang memiliki nilai thitung > ttabel ( $t h: 2,269>\mathrm{t} t: 1,998)$ dan dilihat dari signifikansi yaitu sig. (2-tailed) 0,027 <0,05.

\section{KESIMPULAN}

Didapat hasil dari penelitian bahwa kelas yang melakukan model pembelajaran kuis interaktif who wants to be a millionaire lebih meningkat hasil belajarnya dari yang awalnya rata rata 82,25 dari sebelumnya saat pretest sebesar 70,25. Kenaikan cukup signifikan sebesar 12 angka. Dilihat dari siswa yang tuntas juga meningkat drastis dari yang awalnya hanya 6 siswa saat pretest menjadi 12 siswa saat posttest.

\section{DAFTAR PUSTAKA}

Abidah, A., Hidaayatullaah, H. N., Simamora, R. M., Fehabutar, D., \& Mutakinati, L. (2020). The Impact of Covid-19 to Indonesian Education and Its Relation to the Philosophy of “ Merdeka Belajar ." Studies in Philosophy of Science and Education, 1(1), 38-49. https://doi.org/https://doi.org/10. 15408/sjsbs.v7i3.15104
Arikunto, Suharsimi. (2002). Metodologi Penelitian. Penerbit PT. Rineka Cipta. Jakarta.

Arikunto, Suharsimi. (2003). Prosedur Penelitian, Suatu Praktek. Jakarta: Bina Aksara.

Arikunto, Suharsimi. (2006). Prosedur Penelitian Suatu Pendekatan Praktik. Jakarta: Rineka Cipta.

Brian Robert Cook \& Andrea Babon (2016): Active learning through online quizzes: better learning and less (busy) work, Journal of Geography in Higher Education, DOI:10.1080/03098265.2016.11 85772

Cahyaningtyas, Etika. (2015). Pengaruh model pembelajaran team quiz dan team games tournament (TGT) dalam scientific approach terhadap sikap ilmiah geografi siswa kelas XI IPS mMAN yogyakarta 1 tahun ajaran 2014/2015. Yogyakarta: Skripsi.

Dellos, R. (2015). Kahoot! A digital game resource for learning. INSTRUCTIONAL

TECHNOLOGY, 49. International Journal of Instructional Technology and Distance Learning, 12(4), 49. Tersedia [Online]

Huang, W. H. (2011). Evaluating learners' motivational and cognitive processing in an online game-based learning 
environment. Computers in Human Behavior, 694-704.

Luthra, P. (2020). Covid"s 19 staggering impact on global education. World Economic Forum.

Made, Wena. (2011). Strategi Pembelajaran Inovatif Kontemporer: Suatu Tinjauan. Konseptual Operasional. Jakarta: PT. Bumi Aksara.

Santoso, Suci. (2016). Implementasi media pembelajaran dalam bentuk kuis interaktif untuk meningkatkan hasil belajar siswa pada mata pelajaran jaringan dasar. Surabaya: Jurnal IT-Edu Volume 01 Nomor 01 Tahun 2016, 37-41

Sari, Dian Purnama dkk. (2018). Pengaruh metode kuis interaktif terhadap kemampuan pemecahan masalah matematis mata kuliah trigonometri. Lampung: Jurnal Pendidikan Matematika Volume 12, No. 2, Juli 2018, pp. 63-72.
Sugiyono, (2006). Metode Penelitian Kuantitatif, Kualitatif dan R \& D.Bandung:Alfabeta.

Sugiyono, (2009), Metode Penelitian Kuantitatif, Kualitatif dan R\&D, Bandung : Alfabeta.

Sugiyono. (2011). Metode Penelitian Kuantitatif, Kualitatif dan R\&D. Bandung: Afabeta

Sukmadinata, Nana Syaodih. (2007). Metode Penelitian Pendidikan. Bandung: Rosdakarya.

Sulistyowati, Anik. (2018). Penerapan Model Pembelajaran Quiz Team Untuk Meningkatkan Motivasi Dan Hasil Belajar Materi Pemerintah Kabupaten Dan Kota Pada Siswa Kelas IV SD 4 Kaliwungu. Kudus: Jurnal Prakarsa Paedagogia Vol. 1 No. 2, Desember 2018 Hal. 144-151 UNESCO.(2020).https://en.unesco.org/n ews/137-billion-students-nowhome-covid-19-school-closuresexpand-ministers-scalemultimedia (di akses 22 Maret 2021). 